\title{
Effect of Soil Texture on Water Movement of Porous Ceramic Emitters: A Simulation Study
}

\author{
Yaohui Cai ${ }^{1,+}$, Xiao Zhao ${ }^{1,+}$, Pute $W^{1,2, *}$, Lin Zhang ${ }^{2}$, Delan Zhu ${ }^{1}$ and Junying Chen ${ }^{1}$ \\ 1 Key Laboratory of Agricultural Soil and Water Engineering in Arid and Semiarid Areas, Ministry of \\ Education, Northwest A\&F University, Yangling 712100, China; yaohui_cai@nwafu.edu.cn (Y.C.); \\ zhaoxiao0323@163.com (X.Z.); dlzhu@126.com (D.Z.); cjyrose@126.com (J.C.) \\ 2 Institute of Water Saving Agriculture in Arid Areas of China, Northwest A\&F University, Yangling 712100, \\ China; zl0211wy@163.com \\ * Correspondence: gjzwpt@vip.sina.com; Tel.: +86-029-8709-2860 \\ + These authors contributed equally to this work.
}

Received: 3 December 2018; Accepted: 20 December 2018; Published: 22 December 2018

\begin{abstract}
Choosing reasonable design parameters for ceramic emitters used in subsurface irrigation is important for reducing the deep percolation of water and improving the water use efficiency. Laboratory experiments and numerical simulations with the HYDRUS-2D software were carried out to analyze the effect of soil texture on the infiltration characteristics of porous ceramic emitters used for subsurface irrigation. HYDRUS-2D predictions of emitter discharge in soil and wetting front are in agreement with experimental results, and the HYDRUS-2D model can be used to accurately simulate soil water movement during subsurface irrigation with ceramic emitters in different soil textures. Results show that soil texture has a significant effect on emitter discharge, soil matrix potential around the emitter, and wetting front. For 12 different soil textures, the aspect ratio of the wetting front is basically between 0.84-1.49. In sandy soil, the wetting front mainly appears as an ellipse; but in the clay, the wetting front is closer to a circle. As irrigation time increases, emitter discharge gradually decreases to a stable value; however, emitter discharge in different texture soils is quite different. In order to improve the crop water use efficiency in sandy soil, soil water retention can be improved by adding a clay interlayer or adding water retention agent, reducing the risk of deep percolation and improving the water use efficiency.
\end{abstract}

Keywords: ceramic emitter; HYDRUS; sandy soil; infiltration; discharge

\section{Introduction}

Porous media are commonly used for seepage irrigation, and have a long history of increasing the water use efficiency (WUE), as well as the crop yield. Subsurface irrigation with ceramic devices has significant water-saving effects; therefore, there is potential for using ceramics in subsurface irrigation. Khan et al. [1] found that the water use efficiency reached approximately $94-97 \%$ when pots with different structural sizes were used for irrigation. Zhang et al. [2] found that tomatoes irrigated by ceramic emitters under a working pressure head of $0 \mathrm{~cm}$ achieved the highest yield, approximately $1.17 \mathrm{~kg} \mathrm{pot}^{-1}$, but exhibited the lowest WUE, approximately $24.9 \mathrm{~kg} \mathrm{~m}^{-3}$.

With the advancement of ceramic manufacturing technology, a new porous ceramic emitter based on pot irrigation has been manufactured, and its performance is a significant improvement compared with traditional clay pots and ceramic pipes [3]. The working pressure head of a porous ceramic emitter was generally less than $100 \mathrm{~cm}[4,5]$. The outflow from the emitter could replenish the soil moisture in real-time, effectively irrigating the soil.

When porous ceramic emitters are used in field, a reasonable system design can reduce surface soil evaporation and deep percolation to avoid unnecessary water loss and increase the water use 
efficiency [6]. In general, system design parameters must be determined by infiltration experiments under different working conditions in order to determine the infiltration characteristics of subsurface irrigation emitters (cumulative infiltration, wetting front, and soil water content distribution) [6]. Emitter infiltration characteristics are affected by many factors, such as soil texture, bulk density, initial water content, emitter installation, buried depth, and emitter characteristics (structure size, design discharge, and working pressure head) [7]. The discharge of clay pots in soil is greatly affected by the pot porosity [8]. In practical applications, the pot porosity can be determined according to the water requirements for different crops [9]. Das Gupta et al. [10] used the VS2D model to simulate the infiltration characteristics of a clay ceramic pipe in a specific soil, and found that pipe discharge increased with increasing working pressure head, and soil capillary suction gradually decreased with increasing soil water content. The above research studied the influence of emitter characteristics on the discharge in the soil of clay pots and ceramic pipes by experiments and VS2D simulation.

In recent years, HYDRUS-2D/3D software has been used to study the infiltration characteristics of porous ceramic emitters, pots, and ceramic pipes in soil [11,12]. Cai et al. [4] found that the working pressure head and hydraulic conductivity of porous ceramic emitters had a great influence on the discharge and wetting front in loam. The greater the working pressure head and hydraulic conductivity, the larger the risk of deep percolation. Ren [13] used HYDRUS-3D to simulate the infiltration characteristics for ceramic emitters under $0 \mathrm{~cm}$ working pressure head in clay loam. Emitter discharge gradually stabilized after $12 \mathrm{~h}$, the working pressure head on the ceramic emitter increased, and the stabilized discharge also increased. Wang et al. [7] simulated the infiltration characteristics of clay pipes under negative pressure conditions and found that the larger the negative working pressure head and hydraulic conductivity of the clay pipes, the greater the cumulative soil infiltration. HYDRUS-2D can accurately simulate the infiltration characteristics of ceramic pipes and pots under a working pressure head of $0-200 \mathrm{~cm}$ [5]. When a porous ceramic emitter is buried in different soils, the infiltration characteristics will be different. Therefore, in order to choose reasonable design parameters (tape length, depth, work pressure head), it is important to study the influence of soil texture on the infiltration characteristics of porous ceramic emitters.

The purpose of this study is to: (1) compare experimental infiltration characteristics and HYDRUS-2D simulation results for porous ceramic emitters in clay loam and sandy loam; (2) study the influence of soil texture on the infiltration characteristics of porous ceramic emitters (cumulative infiltration, emitter discharge in soil, and wetting front); and (3) provide reasonable layout suggestions for porous ceramic emitters in sandy soil.

\section{HYDRUS-2D Model}

\subsection{Model Establishment}

Water movement during the infiltration process is considered symmetrical when only one ceramic emitter is used as a cylindrical water source. Assuming the soil is homogeneous and isotropic, the infiltration model can be simplified to a two-dimensional soil water motion and described using the Richards equation, ignoring the effects of temperature and soil water hysteresis on water infiltration. Soil moisture transport is simulated using HYDRUS-2D software (version 2.03, PC Progress, Prague, Czech Republic) [14].

$$
\frac{\partial \theta}{\partial t}=\frac{1}{r} \frac{\partial}{\partial r}\left(r K(h) \frac{\partial h}{\partial r}\right)+\frac{\partial}{\partial z}\left(K(h) \frac{\partial h}{\partial z}\right)+\frac{\partial K(h)}{\partial z}
$$

where, $\theta$ is the volumetric water content $\left[\mathrm{L}^{3} \mathrm{~L}^{-3}\right] ; t$ is the time [T]; $z$ and $r$ are the radial and vertical (positive upward) space coordinates, respectively [L]; and $K(h)$ is the hydraulic conductivity [ $\mathrm{L} \mathrm{T}^{-1}$ ].

The soil water characteristic curve and the soil unsaturated hydraulic conductivity were fit by van Genuchten (1980) and Mualem (1976) [15,16]. 


$$
\begin{gathered}
\theta(h)=\left\{\begin{array}{c}
\theta_{r}+\frac{-\theta_{r}}{\left(1+|\alpha h|^{n}\right)^{m}} h<0 \\
\theta_{s} h \geq 0
\end{array}\right. \\
K(h)=K_{s} S_{e}^{0.5}\left[1-\left(1-S_{e}^{1 / m}\right)^{m}\right]^{2}
\end{gathered}
$$

where, $S_{e}$ is the relative saturation; $K_{s}$ is the saturated hydraulic conductivity; $\theta_{r}$ and $\theta_{s}$ are the residual and saturated soil water contents $\left[\mathrm{L}^{3} \mathrm{~L}^{-3}\right]$, respectively; $\alpha$ is an empirical parameter $\left[\mathrm{L}^{-1}\right]$ whose value is approximately equal to the inverse of the air entry value; and $n$ and $m$ are the van Genuchten-Mualem shape parameters.

\subsection{Model Parameter Settings}

The parameters that need to be set in the process of solving soil moisture by the HYDRUS-2D model include the geometric model, soil hydraulic characteristic parameters, emitter hydraulic characteristic parameters, initial conditions, and boundary conditions. The geometric model and meshing are shown in Figure 1.

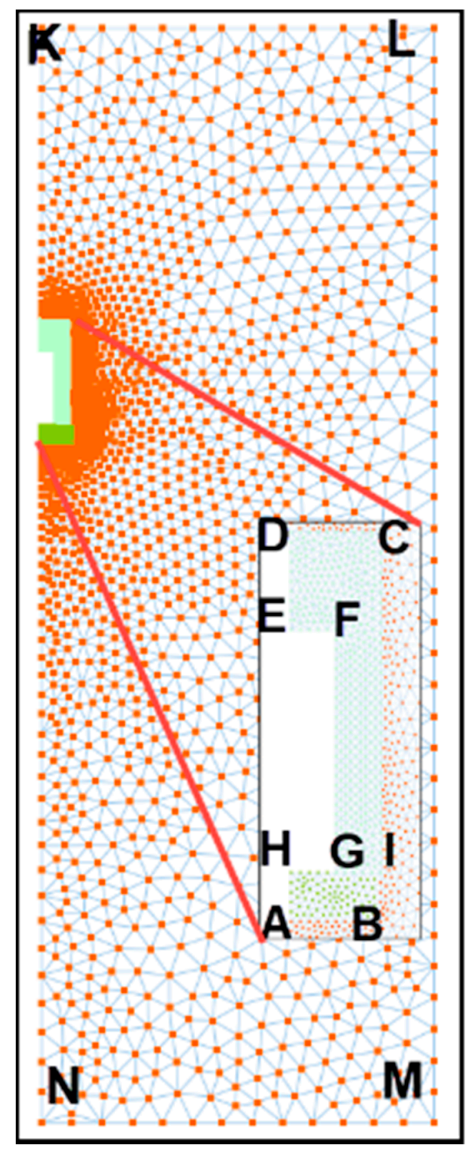

Figure 1. Schematic diagram of the numerical simulation zone for the HYDRUS-2D model.

KLMN is a numerical simulation area with a $0.70 \mathrm{~m}$ height and a width of $0.25 \mathrm{~m}$. It can simulate an emitter spacing of $0.25 \mathrm{~m}$ without considering the intersection of soil moisture (Figure 1 ). The polygon CDEFHGI is a ceramic emitter located in the center of the simulation area with a burial depth of $0.25 \mathrm{~m}$; the $C D$ radius is $0.02 \mathrm{~m}$, the $\mathrm{CI}$ emitter is $0.07 \mathrm{~m}$ long, and the $\mathrm{HG}$ radius is $0.01 \mathrm{~m}$. $\mathrm{ABHI}$ is a plastic cover. The simulated area is discretized into irregular triangular prism elements, and the porous ceramic emitter area is locally encrypted. The simulation area is divided into 4222 two-dimensional grids. 


\subsubsection{Ceramic Emitters and Soil Hydraulic Parameters}

According to the van Genuchten-Mualem model, a ceramic emitter needs to set six parameters $\left(\theta s, \theta r, n, K_{s}\right.$, and $\left.l\right)$. In the simulation process, it is only necessary to set $\alpha$ to a very small value, and the ceramic emitter will remain saturated [5]. Therefore, the value of the ceramic emitter is set to $1.00 \times$ $10^{-8} \mathrm{~cm}^{-1}$. At this time, $\theta s, \theta r, n$, and $l$ are not sensitive to the influence of the experiment results. Therefore, $\theta s, \theta r, n$, and $l$ are set to $0.24,0.001,1.9$, and 0.5 , respectively. $K_{s}$ was set to $0.179 \mathrm{~cm} / \mathrm{h}$ according to the ceramic emitter used in the verification experiment [4]. The soil hydraulic parameter setting is consistent with the two soil parameters used in the verification experiments.

\subsubsection{Boundary and Initial Conditions}

Evaporation is not considered in the simulation, so the upper boundary $\mathrm{KN}$ is set as a no flux boundary. The left and right boundaries KL and NM indicate that there is no water exchange through the soil tank wall and are set as no flux boundaries. The lower boundary LM is set as a free drainage boundary. The internal EFGH of the ceramic emitter is set as a constant head boundary, and the working pressure head is set to $0 \mathrm{~cm}$. Since the ceramic emitter is always saturated during the simulation, the initial negative pressure head is set to $0 \mathrm{~cm}$. In the ceramic infiltration simulation, assuming the soil texture is uniform and the water content is consistent, the initial conditions are set as follows:

$$
h(r, z, t)=h_{0}(0 \leq r \leq 0.25 \mathrm{~m} ; 0 \leq z \leq 0.7 \mathrm{~m}, t=0)
$$

where, $h_{0}$ is the initial soil water content (Table 1 ).

Table 1. Hydraulic parameters of L-soil and H-soil.

\begin{tabular}{cccccccc}
\hline Soil Type & $\begin{array}{c}\theta r \\
\left(\mathbf{c m}^{\mathbf{3}} \mathbf{c m}^{-3}\right)\end{array}$ & $\begin{array}{c}\theta s \\
\left(\mathbf{c m}^{3} \mathbf{c m}^{-3}\right)\end{array}$ & $\begin{array}{c}\alpha \\
\left(\mathbf{m}^{-1}\right)\end{array}$ & $\begin{array}{c}N \\
(-)\end{array}$ & $\begin{array}{c}K s \\
\left(\mathbf{c m ~ h}^{-1}\right)\end{array}$ & $\begin{array}{c}\text { Field Capacity } \\
\left(\mathbf{c m}^{\mathbf{3}} \mathbf{~ c m}^{-3}\right)\end{array}$ & $\begin{array}{c}\text { Initial Pressure } \\
\mathbf{H e a d ~ h}_{\mathbf{0}}(\mathbf{c m})\end{array}$ \\
\hline L-Soil & 0.08 & 0.46 & 0.006 & 1.61 & 0.08 & 0.37 & -3000 \\
H-soil & 0.08 & 0.49 & 0.007 & 2.22 & 0.68 & 0.25 & -8562 \\
\hline
\end{tabular}

\section{HYDRUS-2D Model Validity Verification}

\subsection{Model Verification Experiment}

\subsubsection{Experiment Setup}

The soil box experiment was carried out at Northwest A\&F University, China. The experimental device consists of a Mariotte bottle (Diameter $=10 \mathrm{~cm}$; Volume $=7.85 \mathrm{~L}$ ), conduit pipe, soil box, and porous ceramic emitter (Figure 2). The soil box was made of polymethyl methacrylate and was $40 \mathrm{~cm} \times 40 \mathrm{~cm} \times 70 \mathrm{~cm}$. The porous ceramic emitter was buried at a depth of $25 \mathrm{~cm}$, and the emitter was placed at the corner of the soil box, so that a quarter of the wetting body could be simulated. Experimental soil samples were layered into the soil box according to the designed dry weight of $1.3 \mathrm{~g} / \mathrm{cm}^{3}$. The soil surface was covered with a plastic film to prevent evaporation from affecting the experiment results. The Markov bottle scale was read every $10 \mathrm{~min}$ for the first $120 \mathrm{~min}$ in order to draw the corresponding wet peak. The shape of the wetting front and cumulative infiltration were recorded from 0 to $12 \mathrm{~h}$. The shape of the wetting front was drawn on the front of the polymethyl methacrylate panel every $30 \mathrm{~min}$. The cumulative infiltration is equal to the product of the cross-sectional area and the difference in the water level in the Mariotte bottle. 


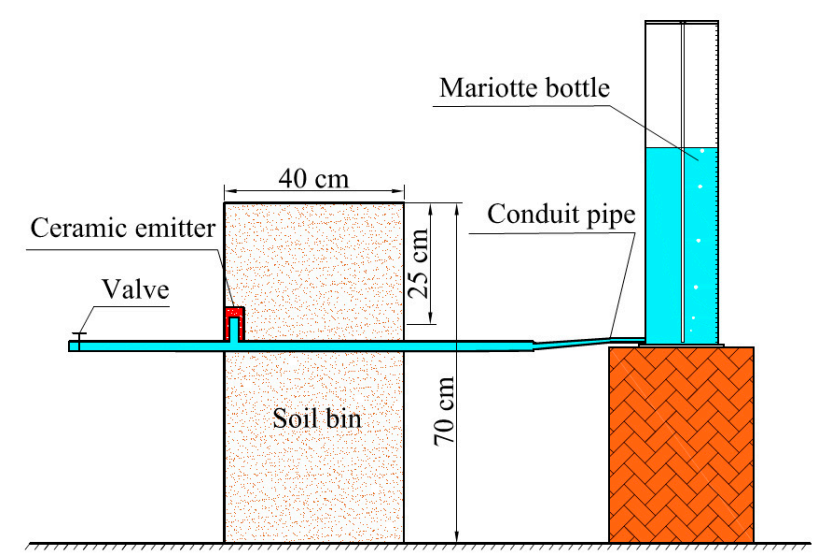

Figure 2. Schematic diagram of the experimental device.

Two different types of soil, Lou-soil (L-soil) and Huangmian-soil (H-soil), were used in the infiltration experiment. L-soil with a bulk density of $1.3 \mathrm{~g} \mathrm{~cm}^{-3}$ was taken from a wheat field in Yangling, Shaanxi Province, China. H-soil with a bulk density of $1.35 \mathrm{~g} \mathrm{~cm}^{-3}$ was taken from an apple forest in Yulin City, Shaanxi Province, China. The soils were collected between a 0-30 cm depth and were air-dried, crushed, mixed, and passed through a $2 \mathrm{~mm}$ sieve. Soil particle composition was determined using a laser particle size analyzer (MS2000, Malvern, UK). L-soil (sand: 43\%, silt: 31\%, clay: $26 \%$ ) was classified as silty loam, and H-soil (sand: $72 \%$, silt: $19 \%$, clay: $9 \%$ ) was classified as sandy loam [17]. The soil water retention curve was determined by a high-speed freezing centrifuge (CR21G PF, Hitachi, Japan), and the soil hydraulic parameters [15] were fit using the RETC code [18]. Saturated soil hydraulic conductivity was measured using the falling head method (Table 1).

\subsubsection{Simulation Effectiveness Evaluation}

The effectiveness of the HYDRUS-2D simulation is evaluated using the coefficient of residual mass (CRM), root mean square error (RMSE), and normalized root mean squared error (NRMSE).

$$
\begin{aligned}
C R M & =\frac{\sum_{i=1}^{n} M_{e}-\sum_{i=1}^{n} S_{i}}{\sum_{i=1}^{n} M_{e}} \\
\text { RMSE } & =\sqrt{\frac{1}{x} \sum_{i=1}^{n}\left(S_{i}-M_{\mathcal{e}}\right)^{2}} \\
\text { NRMSE } & =\frac{\sqrt{\frac{1}{x} \sum_{i=1}^{n}\left(S_{i}-M_{e}\right)^{2}}}{\bar{M}}
\end{aligned}
$$

where, $x$ is the number of measured data and analog data; $S_{i}$ is the model simulation value; $M_{e}$ is the measured value; and $\bar{M}$ is the mean measured value.

A CRM value close to 0 indicates that the model simulation effect is good. The smaller the RMSE value is, the better the model fitting is. An NRMSE value less than 0.20 indicates a good consistency between the predictions and measured results; whereas an NRMSE value greater than 0.30 indicates a considerable difference between the predictions and measured results. Under optimal conditions, it is assumed that the CRM, RMSE, and NRMSE are close to 0 .

\subsection{Model Verification Results}

Figure 3 shows the measured and simulated emitter discharge and wetting front with time for a porous ceramic emitter buried in two different soils. At the beginning of irrigation, emitter discharge drops rapidly and then gradually decreases (Figure 3a). As irrigation time increases, discharge gradually approaches a stable value. The simulated discharge is consistent with the measured data, 
and the trends are similar. For H-soil, the RMSE is close to 0 , the CRM absolute value is less than $10 \%$, and the NRMSE is less than 0.2 , indicating that the HYDRUS-2D is highly suitable for simulating emitter discharge for a ceramic emitter buried in H-soil (Table 2). For L-soil, the RMSE is close to 0 and the CRM absolute value is less than $10 \%$, but the NRMSE is between 0.2 and 0.3 , which is due to the large discharge variation at the beginning of irrigation, resulting in a large discharge fluctuation due to the data collection interval. The NRMSE is larger, but it still less than 0.3 ; therefore, HYDRUS-2D can simulate the emitter discharge in L-soil.
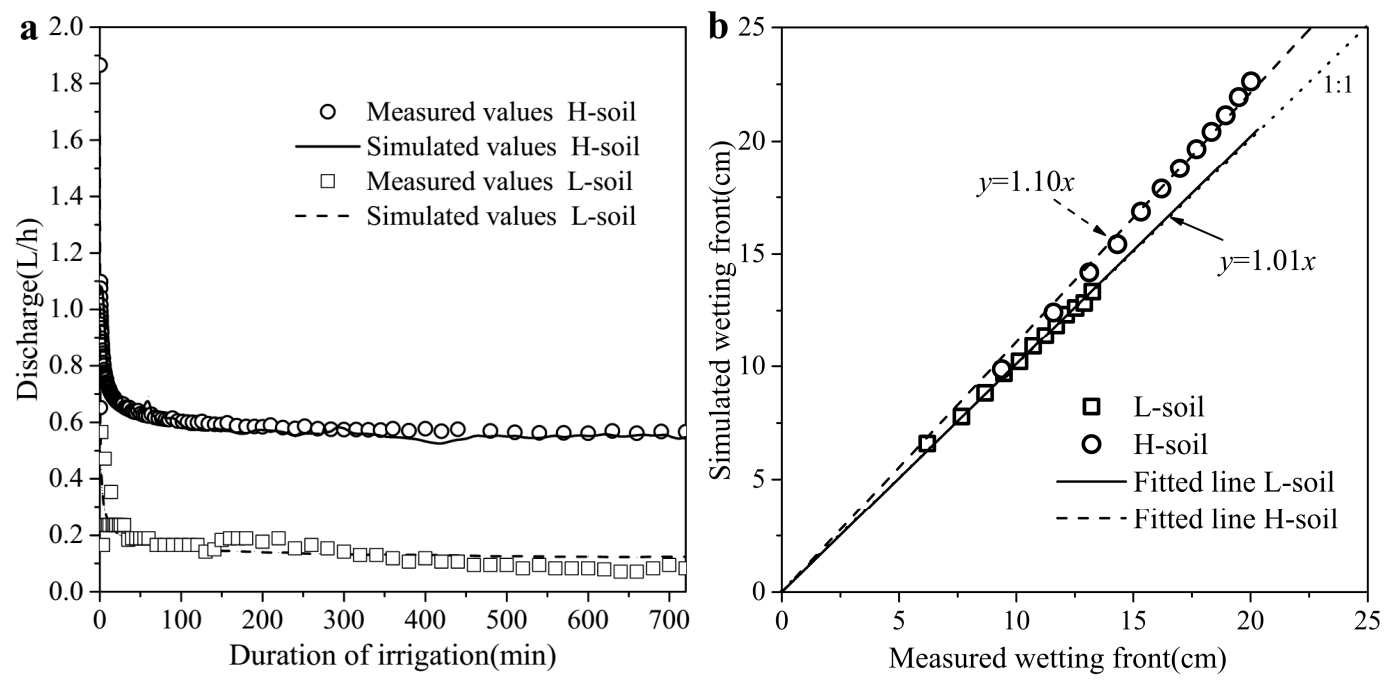

Figure 3. Graphs showing the measured and simulated emitter discharge and wetting front.

Table 2. Statistical indicators of measured and simulated discharge and wetting front in two different soils.

\begin{tabular}{ccccccc}
\hline \multirow{2}{*}{$\begin{array}{c}\text { Statistical } \\
\text { Indicators }\end{array}$} & \multicolumn{3}{c}{ Discharge } & \multicolumn{3}{c}{ Wetting Front } \\
\cline { 2 - 7 } & CRM & RMSE & NRMSE & CRM & RMSE & NRMSE \\
\hline L-soil & $-2.00 \%$ & 0.05 & 0.26 & $1.5 \%$ & 0.17 & 0.02 \\
H-soil & $-0.02 \%$ & 0.04 & 0.07 & $9.9 \%$ & 1.77 & 0.11 \\
\hline
\end{tabular}

The simulated and measured wetting fronts in L-soil show a 1:1 linear relationship (Figure 3b). The simulated wetting front in H-soil is somewhat larger, and the linear relationship between the measured and simulated values is $1: 1$. This may be due to the slightly larger value of the soil characteristic parameter $n$ for the H-soil soil, indicating that the rate of the simulated moisture diffusion is increased. Therefore, the simulated wetting front values are larger than the measured value. However, for both soils, the RMSE is close to 0 , the absolute value of CRM is also less than $10 \%$, and the NRMSE is less than 0.2 (Table 2). The statistical values meet the requirements of the simulation prediction. Results show that the simulated wetting front agreed well with the measured results for the two soils.

Based on the emitter discharge and the wetting front, it can be concluded that the HYDRUS-2D model gives highly accurate predictions for soil water movements under subsurface irrigation from ceramic emitters buried in two different soils. Thus, numerical simulations employing the HYDRUS-2D-2D model are used in this study to investigate the effect of soil texture on emitter discharge and wetting front.

\section{HYDRUS-2D Model Application}

Emitter discharge is primarily affected by soil texture when the working pressure head and hydraulic conductivity of the ceramic emitter are constant. Twelve representative soils in HYDRUS-2D 
were selected for analysis (Table 3) [14,19]. This soil database is used to obtain the bulk density, as well as the clay and sand contents, for the 12 textural classifications. Saturated water content $(\theta s)$ is inferred from bulk density. Meanwhile, saturated hydraulic conductivity $\left(K_{s}\right)$ and water retention parameters $(\theta r, n$, and $l)$ are computed using the saturated water content, as well as the clay and sand contents [20]. Field capacity is calculated by the method described by Twarakavi et al. [21].

Table 3. Hydraulic parameters of 12 representative soils.

\begin{tabular}{|c|c|c|c|c|c|c|c|}
\hline Soil Texture & $\begin{array}{c}\theta r \\
\left(\mathrm{~cm}^{3} \mathrm{~cm}^{-3}\right)\end{array}$ & $\begin{array}{c}\theta s \\
\left(\mathrm{~cm}^{3} \mathrm{~cm}^{-3}\right)\end{array}$ & $\begin{array}{c}\alpha \\
\left(m^{-1}\right)\end{array}$ & $\begin{array}{l}N \\
(-)\end{array}$ & $\begin{array}{c}K s \\
\left(\mathrm{~cm} \mathrm{~h}^{-1}\right)\end{array}$ & $\begin{array}{l}\text { Field Capacity } \\
\left(\mathrm{cm}^{3} \mathrm{~cm}^{-3}\right)\end{array}$ & $\begin{array}{c}\text { Initial Pressure } \\
\text { Head }(\mathrm{cm})\end{array}$ \\
\hline Sand & 0.045 & 0.43 & 0.145 & 2.68 & 29.7 & 0.067 & -3000 \\
\hline Loamy Sand & 0.057 & 0.41 & 0.124 & 2.28 & 14.6 & 0.094 & -3000 \\
\hline Sandy Loam & 0.065 & 0.41 & 0.075 & 1.89 & 4.42 & 0.139 & -3000 \\
\hline Loam & 0.078 & 0.43 & 0.036 & 1.56 & 1.04 & 0.220 & -3000 \\
\hline Silt & 0.034 & 0.46 & 0.016 & 1.37 & 0.25 & 0.286 & -3000 \\
\hline Silty Loam & 0.067 & 0.45 & 0.02 & 1.41 & 0.45 & 0.272 & -3000 \\
\hline Sandy Clay Loam & 0.100 & 0.39 & 0.059 & 1.48 & 1.31 & 0.227 & -3000 \\
\hline Clay Loam & 0.095 & 0.41 & 0.019 & 1.31 & 0.26 & 0.295 & -3000 \\
\hline Silty Clay Loam & 0.089 & 0.43 & 0.010 & 1.23 & 0.07 & 0.348 & -3000 \\
\hline Sandy Clay & 0.100 & 0.38 & 0.027 & 1.23 & 0.12 & 0.306 & -3000 \\
\hline Silty Clay & 0.070 & 0.36 & 0.005 & 1.09 & 0.02 & 0.336 & -3000 \\
\hline Clay & 0.068 & 0.38 & 0.008 & 1.09 & 0.2 & 0.34 & -3000 \\
\hline
\end{tabular}

\subsection{Infiltration Characteristics}

\subsubsection{Cumulative Infiltration, Discharge, and Matrix Potential}

Table 4 shows data for the cumulative infiltration of the porous ceramic emitter at $12 \mathrm{~h}$ under different soil textures. The cumulative infiltration of the emitter in silty clay, sandy clay, and clay is small, between $0.07 \mathrm{~L}\left(\mathrm{dm}^{3}\right)$, and $0.28 \mathrm{~L}$, respectively (Table 4$)$. This is primarily because the clay content in these soils is too high, so the contact area between the soil particles is large and the pores are small, reducing the saturated water conductivity, increasing the difficulty of soil water diffusion, and decreasing the cumulative infiltration. The cumulative infiltration of loam is $1.28 \mathrm{~L}$. Although the saturated hydraulic conductivity of loam is smaller than that of sand, the cumulative infiltration is the largest.

Table 4. Cumulative infiltration and aspect ratio of ceramic emitters in different soils.

\begin{tabular}{ccccccccccccc}
\hline & Clay & $\begin{array}{c}\text { Clay } \\
\text { Loam }\end{array}$ & Loam & $\begin{array}{c}\text { Loamy } \\
\text { Sand }\end{array}$ & $\begin{array}{c}\text { Sandy } \\
\text { Loam }\end{array}$ & Sand & $\begin{array}{c}\text { Sandy Clay } \\
\text { Loam }\end{array}$ & $\begin{array}{c}\text { Sandy } \\
\text { Clay }\end{array}$ & $\begin{array}{c}\text { Silt } \\
\text { Silty Clay } \\
\text { Loam }\end{array} \begin{array}{c}\text { Silty } \\
\text { Clay }\end{array}$ & $\begin{array}{c}\text { Silty } \\
\text { Loam }\end{array}$ \\
\hline $\begin{array}{c}\text { Aspect } \\
\text { ratio (\%) }\end{array}$ & 97.34 & 94.97 & 97.49 & 125.16 & 108.85 & 148.96 & 97.19 & 93.23 & 95.02 & 94.58 & 83.84 & 96.07 \\
$\begin{array}{c}\text { Cumulative } \\
\text { infiltration } \\
(12 \text { h) (L) }\end{array}$ & 0.28 & 0.73 & 1.28 & 1.01 & 1.23 & 0.94 & 0.73 & 0.25 & 1.00 & 0.40 & 0.07 & 1.23 \\
\hline
\end{tabular}

Figure 4 shows the emitter discharge in loam and sand and the matric potential around the emitter with time. As irrigation time increases, emitter discharge gradually decreases to a stable value of $0.08 \mathrm{~L} / \mathrm{h}$ and $0.10 \mathrm{~L} / \mathrm{h}$ for sand and loam, respectively. At this time, the matric potential around the emitter is about $-10 \mathrm{~cm}$ in sand and is $-14 \mathrm{~cm}$ in loam. Under zero working pressure head, the emitter effluent primarily depends on the matrix suction of the soil [22,23]. During irrigation, soil matrix potential around the emitter gradually increases (the absolute value gradually decreases), so the water potential difference inside and outside the emitter gradually decreases, which in turn reduces the emitter discharge. Because the sandy soils have a small saturated water content and field capacity, the soil around the emitter will be saturated quickly; therefore, the soil matrix potential around the emitter will be smaller. Since the internal working water pressure of the emitter is $0 \mathrm{~cm}$, the water potential difference between the inside and the outside of the emitter is $10 \mathrm{~cm}$ and $14 \mathrm{~cm}$ for sand and loam, respectively, so the emitter discharge in loam is also 1.4 times larger than in sand. 


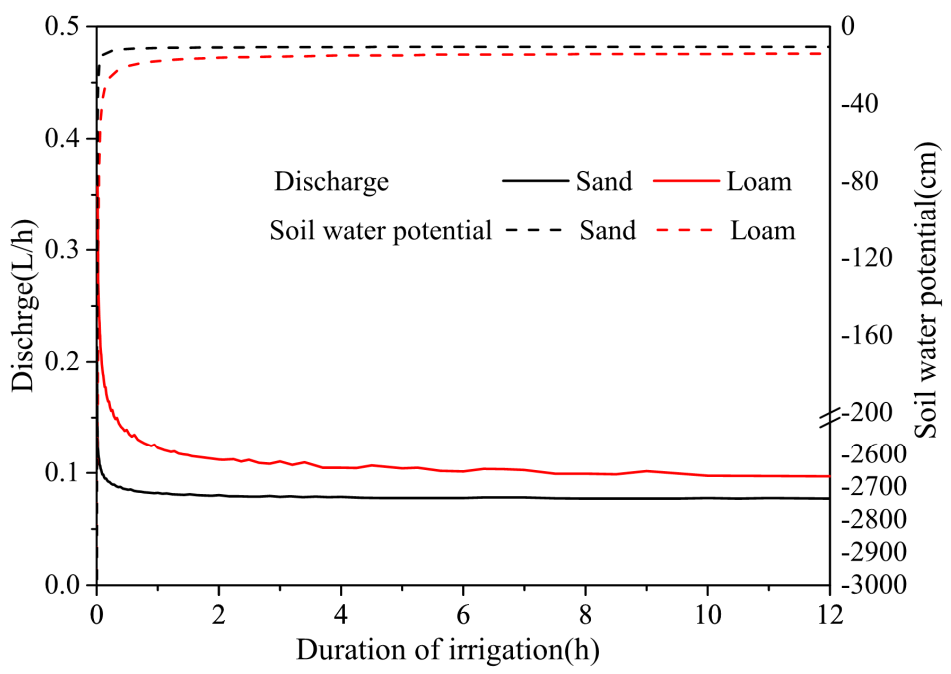

Figure 4. Graph showing emitter discharge and the soil water potential around the emitter in the loam and sand through time.

The simulated cumulative infiltrations are all smaller than the measured cumulative from the experiment (Table 3). This is mainly because the saturated water content of the two soils used in the experiment is greater than the saturated water content of the soils used in simulations, but the saturated water contents are all $0.46 \mathrm{~cm}^{3} / \mathrm{cm}^{3}$ for the 12 kinds of soils, which is provided in HYDRUS. Therefore, for the same soil texture, such as L-soil (silty loam) and silty loam, the measured saturated water content is higher, resulting in a larger cumulative infiltration.

\subsubsection{Wetting Front}

Figure 5 shows the wetting front for different soil textures after $12 \mathrm{~h}$. For sandy soil with a high permeability and low saturated water content, the wetting front mainly appears as an ellipse, the downward vertical wetting front is larger than the horizontal wetting front, and the horizontal wetting front is larger than the upward vertical wetting front. However, in clay soils with a smaller permeability and higher saturated water content, the wetting front appears to be closer to a circle. The ratio of the downward vertical wetting front to the horizontal wetting front (aspect ratio) is shown in Table 4. Aspect ratios are between $83.34 \%-148.96 \%$. For clay soils, the aspect ratio is closer to 1 . For sandy soils, the aspect ratio is significantly greater than 1 , and water is more likely to move to the lower part of the soil layers. For silty soils, the aspect ratio is less than 1 . This is mainly due to the fact that the porous ceramic emitter is installed upwards in this study, and the bottom of the emitter is a $5 \mathrm{~mm}$ thick impervious bottom cover, limiting water movement in the lower soil layers. The change in aspect ratio is mainly determined by the mass fraction of clay particles in the soil [24]. Sandy soil has less clay content and a high sand content, creating much larger pores and a small specific surface area, resulting in a strong water permeability. However, for sticky soil, the clay content is higher and specific surface area is larger, so the soil's matrix suction is larger, but water permeability is weak. Therefore, as clay content increases, the soil matrix suction increases but water conductivity decreases, increasing water retention. During infiltration, water transport within soil is affected by both matrix potential (matrix suction) and gravitational potential [25]. Under the same experimental conditions, the effect of the matrix potential in sandy soil is smaller than gravitational potential, while the effect of the matrix potential in clay soil is much greater than gravitational potential. Therefore, during infiltration, the effect of matrix potential increases as clay content increases, and the effect of gravity potential decreases; thus, the aspect ratio is gradually reduced, and the wetting front gradually changes from an ellipse to a circle. When ceramic emitters are buried in sandy soil, the risk of deep percolation is high due to poor water retention; therefore, some engineering measures must be taken to reduce the risk of deep percolation and improve the crop water use efficiency in sandy soil. 

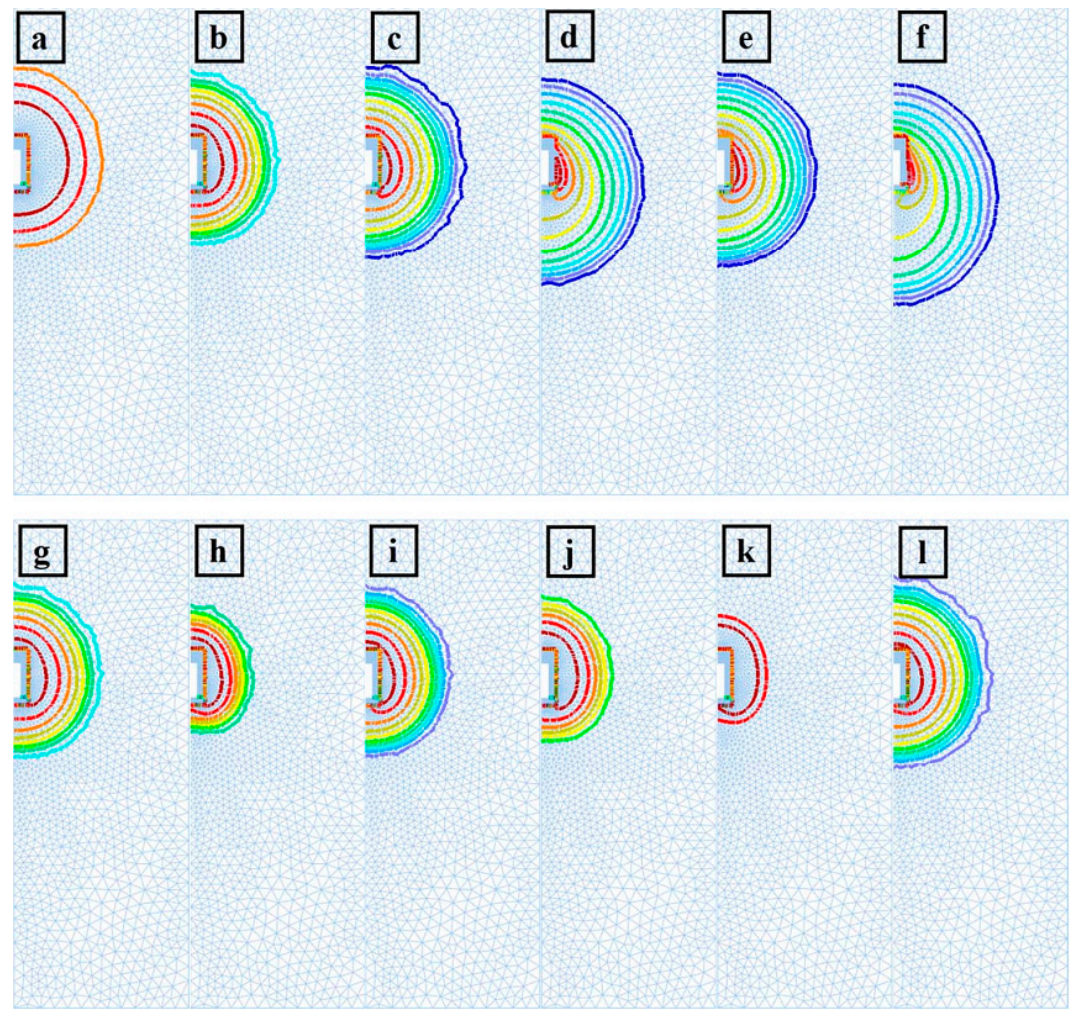

Figure 5. Images showing the wetting front for different soil textures after $12 \mathrm{~h}$ ((a) clay, (b) clay loam, (c) loam, (d) loamy sand, (e) sandy loam, (f) sand, (g) sandy clay loam, (h) sandy clay, (i) silt, (j) silty clay loam, (k) silty clay, (1) silty loam).

\subsection{Optimization Layout of Porous Ceramic Emitters in Sandy Soil}

Poor water retention is not conducive to crop growth. In sandy soil, the field capacity is lower, and irrigation water is easily transported to the lower soil layers. In order to improve the crop water use efficiency in sandy soil, there are two feasible ways to improve soil water retention or prevent soil moisture from migrating to a deeper layer [26]. If a weak aquifer is placed $25 \mathrm{~cm}$ below the emitter, similar to adding a layer of clay during an experiment, it may prevent the soil moisture from migrating downward. Figure 6 shows the change in wetting front at different times in the sand when the clay aquifer (Figure 1) is placed under the emitter. As irrigation time increases, irrigation water in the sand gradually migrates downward and reaches the clay layer at around $20 \mathrm{~h}$. The irrigation water is then transferred to the horizontal direction by the clay layer barrier, and the infiltrated water accumulates in the clay layer. The soil water content in the clay layer gradually reaches saturation at $0.38 \mathrm{~cm}^{3} / \mathrm{cm}^{3}$ (Table 1). After $60 \mathrm{~h}$, the clay layer was completely saturated. At this time, water began to migrate downward through the clay layer. The soil water content below the clay layer was already around $0.11 \mathrm{~cm}^{3} / \mathrm{cm}^{3}$, and deep percolation began to occur at $120 \mathrm{~h}$. The deep percolation rate (deep percolation rate $=$ deep percolation discharge $/$ irrigation amount $\times 100 \%$ ) was $5.0 \%$. Without the treatment of the clay layer, the deep percolation rate was as high as $17.8 \%$. Therefore, in the area where the soil texture is sandy and a ceramic emitter is used for irrigation, the use of a clay layer can reduce deep percolation and improve the water use efficiency. 


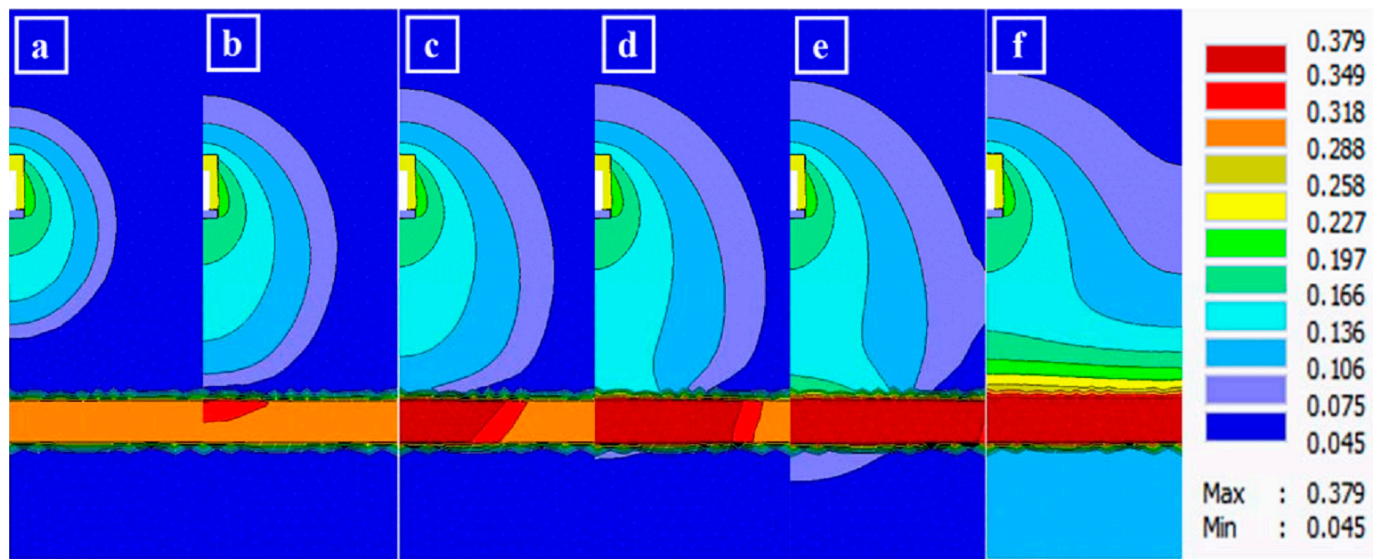

Figure 6. Images showing the change in wetting front at different times in sand above a clay aquifer ((a) $12 \mathrm{~h},(\mathbf{b}) 24 \mathrm{~h},(\mathbf{c}) 36 \mathrm{~h},(\mathbf{d}) 48 \mathrm{~h},(\mathbf{e}) 60 \mathrm{~h},(\mathbf{f}) 120 \mathrm{~h})$.

The process of installing a clay layer requires a large workload and is suitable for some areas where desertification control is required. For other sandy soil areas, a water retaining agent may be added to the sandy soil to improve its texture and water retention $[27,28]$. Table 5 shows the hydraulic parameters of sandy loam and polyacrylamide-mixed (PAM-mixed) sandy loam [29,30].

Table 5. Hydraulic parameters of sandy loam and PAM-mixed sandy loam.

\begin{tabular}{|c|c|c|c|c|c|}
\hline Soil Texture & $\begin{array}{c}\theta r \\
\left(\mathrm{~cm}^{3} \mathrm{~cm}^{-3}\right)\end{array}$ & $\begin{array}{c}\theta s \\
\left(\mathrm{~cm}^{3} \mathrm{~cm}^{-3}\right)\end{array}$ & $\begin{array}{c}\alpha \\
\left(m^{-1}\right)\end{array}$ & $\begin{array}{l}n \\
(-)\end{array}$ & $\begin{array}{c}K s \\
\left(\mathrm{~cm} \mathrm{~h}^{-1}\right)\end{array}$ \\
\hline Sandy loam & 0.083 & 0.312 & 0.016 & 1.594 & 2.73 \\
\hline PAM-mixed sandy loam & 0.145 & 0.353 & 0.030 & 1.561 & 2.39 \\
\hline
\end{tabular}

Figure 7 shows the wetting front for a ceramic emitter buried in sandy loam and PAM-mixed sandy loam after $120 \mathrm{~h}$ of irrigation. The wetting front changes significantly after the addition of the water retaining agent. At $120 \mathrm{~h}$, the water content in sandy loam soil is smaller than that of PAM-mixed sandy loam. The highest water contents are $0.29 \mathrm{~cm}^{3} \mathrm{~cm}^{-3}$ and $0.33 \mathrm{~cm}^{3} \mathrm{~cm}^{-3}$, respectively; however, the cumulative infiltration of the emitter in the sandy loam is significantly higher than in the PAM-mixed sandy loam, which is $36.1 \mathrm{~L}$ and $19.5 \mathrm{~L}$, respectively, indicating that more irrigation water in the sandy loam migrates to the deeper layers, resulting in deep percolation. Deep percolation rates in the two soils are $42.7 \%$ and $8.2 \%$, respectively. Therefore, the use of a water retention agent can significantly improve soil water retention and reduce the risk of deep percolation.

Overall, there are two effective ways to reduce deep water percolation: placing a clay interlayer and adding water retention agent. In a subsurface irrigation system, the deep percolation rate needs to be less than $5 \%$ to improve benefits for crops. Therefore, the method of placing a clay interlayer may be better than adding water retention agent in sandy soil because of the high water use efficiency. In the areas where land levelling and desertification control are required, this method could be a good choice. On the other hand, this method could cost a large amount manpower and material resources, and not be effective. Therefore, in areas where there is a need for deep tillage, adding water retention agent would be simple and useful. 


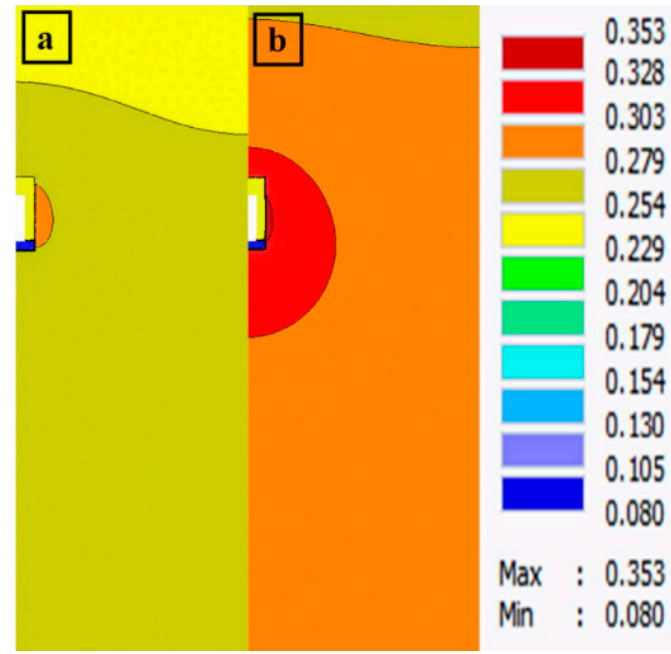

Figure 7. Wetting front for a ceramic emitter buried in sandy loam and PAM mixed sandy loam after 120 h ((a). Sandy loam; (b), Sandy loam with water retaining agent).

\section{Conclusions}

This study compared the simulated and measured infiltration characteristics of porous ceramic emitters in L-soil and H-soil. The HYDRUS-2D model was used to simulate water movement with ceramic emitters in different soils.

For 12 different soil texture conditions, the aspect ratio of the wetting front is basically between 0.84-1.49. In sandy soil, the wetting front appears as an ellipse; but in clay soil, the wetting front is closer to a circle. As irrigation time increases, emitter discharge gradually decreases to a stable value; however, emitter discharge for different texture soils is quite different. The emitter discharge in silty clay, sandy clay, and clay is small. The clay content in these soils is too high, increasing the difficulty of soil water diffusion, and decreasing the emitter discharge. The emitter discharge in loam is 1.4 times that in sand, because the soil matrix potential around the emitter is smaller due to the lower saturated soil moisture content and field capacity.

In order to improve the crop water use efficiency in sandy soil, water retention can be improved by adding a clay interlayer or water retention agent to reduce the risk of deep percolation. The method of placing a clay interlayer is better than adding water retention agent in sandy soil because of the high water use efficiency. However, in areas where there is a need for deep tillage, adding water retention agent could be a good choice.

Author Contributions: Data curation, Y.C.; Funding acquisition, L.Z.; Investigation, Y.C.; Resources, D.Z.; Supervision, P.W.; Writing original draft, X.Z. and J.C.; Writing review \& editing, L.Z.

Funding: This research was funded by the National Natural Science Foundation of China (551879225), Key Research and Development Program of Ningxia Hui Autonomous Region (2018BBF02006), Key Research and Development Program of Shaanxi Province (2017NY-118), Science and Technology Program of Yangling Demonstration Zone (2017NY-28), and the National Science and Technology Support Program (2015BAD22B01-02).

Conflicts of Interest: The authors declare no conflict of interest.

\section{References}

1. Khan, N.N.; Islam, M.; Islam, S.; Moniruzzaman, S.M. Effect of Porous Pipe Characteristics on Soil Wetting Pattern in a Negative Pressure Difference Irrigation System. Am. J. Eng. Res. 2015, 4, 1-12.

2. Zhang, J.; Saito, H.; Kato, M. Study on Subsurface Irrigation Using Ceramic Pitcher on Tomato Cultivation in Greenhouse. J. Arid Land Stud. 2009, 267, 265-267. [CrossRef]

3. Cai, Y.; Wu, P.; Zhu, D.; Li, X.; Zhang, L.; Chen, J. Preparation technology optimization of diatomite porous ceramic irrigation emitter. Trans. Chin. Soc. Agric. Eng. 2015, 31, 70-76. [CrossRef] 
4. Cai, Y.; Wu, P.; Zhang, L.; Zhu, D.; Wu, S.; Zhao, X.; Chen, J.; Dong, Z. Prediction of flow characteristics and risk assessment of deep percolation by ceramic emitters in loam. J. Hydrol. 2018, 566, 901-909. [CrossRef]

5. Siyal, A.A.; Skaggs, T.H. Measured and simulated soil wetting patterns under porous clay pipe sub-surface irrigation. Agric. Water Manag. 2009, 96, 893-904. [CrossRef]

6. Lamm, R.F.; Ayars, E.J.; Nakayama, S.F. Microirrigation for Crop Production: Design, Operation, and Management; Elsevier: Amsterdam, The Netherlands, 2006.

7. Wang, J.; Huang, Y.; Long, H.; Hou, S.; Xing, A.; Sun, Z. Simulations of water movement and solute transport through different soil texture configurations under negative-pressure irrigation. Hydrol. Process. 2017, 31, 2599-2612. [CrossRef]

8. Naik, B.S.; Panda, R.K.; Nayak, S.C.; Sharma, S.D. Hydraulics and salinity profile of pitcher irrigation in saline water condition. Agric. Water Manag. 2008, 95, 1129-1134. [CrossRef]

9. Hajjaji, M.; Mezouari, H. A calcareous clay from Tamesloht (Al Haouz, Morocco): Properties and thermal transformations. Appl. Clay Sci. 2011, 51, 507-510. [CrossRef]

10. Das Gupta, A.; Babel, M.S.; Ashrafi, S. Effect of soil texture on the emission characteristics of porous clay pipe for subsurface irrigation. Irrig. Sci. 2009, 27, 201-208. [CrossRef]

11. Siyal, A.A.; van Genuchten, M.T.; Skaggs, T.H. Solute transport in a loamy soil under subsurface porous clay pipe irrigation. Agric. Water Manag. 2013, 121, 73-80. [CrossRef]

12. Siyal, A.A.; Van Genuchten, M.T.; Skaggs, T.H. Performance of pitcher irrigation system. Soil Sci. 2009, 174, 312-320. [CrossRef]

13. Ren, G. Research on Soil Water Movement Characteristics under Microporous Ceramic Emitter Irrigation. Master's Thesis, Northwest A \& F University, Yangling, China, 2016.

14. Šimůnek, J.; van Genuchten, M.T.; Sejna, M. The HYDRUS Software Package for Simulating the Two- and Three-Dimensional Movement of Water, Heat, and Multiple Solutes in Variably-Saturated Porous Media. Tech. Manual 2012, 230. [CrossRef]

15. Van Genuchten, M.T. A Closed-form Equation for Predicting the Hydraulic Conductivity of Unsaturated Soils1. Soil Sci. Soc. Am. J. 1980, 44, 892-898. [CrossRef]

16. Mualem, Y. A new model for predicting the hydraulic conduc. Water Resour. Res. 1976, 12, 513-522. [CrossRef]

17. USDA. USDA Textural Soil Classification. Soil Mechanics Level I Module 3; United States Department of Agriculture, National Employee Staff, Soil Conservation Service: Washington, DC, USA, 1987.

18. Schaap, M.G.; Leij, F.J.; van Genuchten, M.T. Rosetta: A computer program for estimating soil hydraulic parameters with hierarchical pedotransfer functions. J. Hydrol. 2001, 251, 163-176. [CrossRef]

19. Fan, Y.W.; Huang, N.; Zhang, J.; Zhao, T. Simulation of soil wetting pattern of vertical moistube-irrigation. Water 2018, 10, 601. [CrossRef]

20. Carsel, R.F.; Parrish, R.S. Developing joint probability descriptions of soil water retention. Water Resour. Res. 1988, 24, 755-769. [CrossRef]

21. Twarakavi, N.K.C.; Sakai, M.; Šimůnek, J. An objective analysis of the dynamic nature of field capacity. Water Resour. Res. 2009. [CrossRef]

22. Kacimov, A.R.; Obnosov, Y.V. Tension-saturated and unsaturated flows from line sources in subsurface irrigation: Riesenkampf's and Philip's solutions revisited. Water Resour. Res. 2016, 52, 1866-1880. [CrossRef]

23. Kacimov, A.R.; Obnosov, Y.V.; Šimůnek, J. Steady Flow from an Array of Subsurface Emitters: Kornev's Irrigation Technology and Kidder's Free Boundary Problems Revisited. Transp. Porous Media 2018, 121, 643-664. [CrossRef]

24. Naglič, B.; Kechavarzi, C.; Coulon, F.; Pintar, M. Numerical investigation of the influence of texture, surface drip emitter discharge rate and initial soil moisture condition on wetting pattern size. Irrig. Sci. 2014, 32, 421-436. [CrossRef]

25. Jury, W.; Horton, R. Soil Physics; John Wilcy \& Sons Inc.: Hoboken, NJ, USA, 2004; ISBN 0-471-05965-x(cloth).

26. El-Nesr, M.N.; Alazba, A.A.; Šimůnek, J. HYDRUS simulations of the effects of dual-drip subsurface irrigation and a physical barrier on water movement and solute transport in soils. Irrig. Sci. 2014, 32, 111-125. [CrossRef]

27. Trifunovic, B.; Gonzales, H.B.; Ravi, S.; Sharratt, B.S.; Mohanty, S.K. Dynamic effects of biochar concentration and particle size on hydraulic properties of sand. Land Degrad. Dev. 2018, 29, 884-893. [CrossRef] 
28. Zhang, J.; Chen, Q.; You, C. Biochar Effect on Water Evaporation and Hydraulic Conductivity in Sandy Soil. Pedosphere 2016, 26, 265-272. [CrossRef]

29. Han, D.; Wei, Z.; Yu, J.; Song, R. Influence Mechnisms of Wetting Rate on Soil Saturated Hydraulic Conductivity. J. Soil Water Conserv. 2015, 29, 43-51. [CrossRef]

30. Han, D. The Study on Effect and Mechanism of Wetting Rate and Chemical Materials on Soil Hydraulic Properties. Ph.D. Thesis, Inner Mongolia Agricultural University, Hohehot Municipality, China, 2016.

(c) (1) 